\title{
Testing new strategies to improve the recovery of phosphorus from anaerobically digested organic fraction of municipal solid waste
}

Oliveira, Verónica; DiasFerreira, Celia; Labrincha, João; Rocha, Joana L.; Kirkelund, Gunvor Marie

Published in:

Journal of Chemical Technology and Biotechnology

Link to article, DOI:

$10.1002 / j c t b .6037$

Publication date:

2019

Document Version

Peer reviewed version

Link back to DTU Orbit

Citation (APA):

Oliveira, V., DiasFerreira, C., Labrincha, J., Rocha, J. L., \& Kirkelund, G. M. (2019). Testing new strategies to improve the recovery of phosphorus from anaerobically digested organic fraction of municipal solid waste. Journal of Chemical Technology and Biotechnology. https://doi.org/10.1002/jctb.6037

\section{General rights}

Copyright and moral rights for the publications made accessible in the public portal are retained by the authors and/or other copyright owners and it is a condition of accessing publications that users recognise and abide by the legal requirements associated with these rights.

- Users may download and print one copy of any publication from the public portal for the purpose of private study or research.

- You may not further distribute the material or use it for any profit-making activity or commercial gain

- You may freely distribute the URL identifying the publication in the public portal 


\title{
Testing new strategies to improve the recovery of phosphorus from
}

\section{anaerobically digested organic fraction of municipal solid waste}

\author{
Verónica Oliveira $^{1,2 *}$, Celia Dias-Ferreira ${ }^{1,2,3}$, João Labrincha ${ }^{2}$, Joana L. Rocha ${ }^{1}$, Gunvor M. \\ Kirkelund $^{4}$ \\ ${ }^{1}$ Polytechnic Institute of Coimbra \& Research Centre for Natural Resources, Environment and Society \\ (CERNAS), College of Agriculture, Bencanta, 3045-601 Coimbra, Portugal \\ ${ }^{2}$ Materials and Ceramic Engineering Department, CICECO, University of Aveiro, Campus \\ Universitário de Santiago, 3810-193 Aveiro, Portugal \\ ${ }^{3}$ Universidade Aberta, Lisboa, Portugal \\ ${ }^{4}$ Department of Civil Engineering, Technical University of Denmark, building 118, 2800 Kgs. \\ Lyngby, Denmark \\ "corresponding author. Tel.: +351 239802600 Fax: +351 239802979 E-mail address: \\ veronica.oliveira@esac.pt
}

\begin{abstract}
BACKGROUND: This work is focused on phosphorus recovery from anaerobically digested organic fraction of municipal solid waste (referred to as "digestate") as a fertiliser. The main purpose was to propose and test modifications to the electrodialytic process that increase phosphorus extraction, improve the quality of the fertiliser by removing contaminants, and reduce hydraulic retention time to
\end{abstract}

This article has been accepted for publication and undergone full peer review but has not been through the copyediting, typesetting, pagination and proofreading process which may lead to differences between this version and the Version of Record. Please cite this article as doi: $10.1002 /$ jctb. 6037 
allow for smaller system footprints. Strategies tested were: i) lowering the $\mathrm{pH}$ of the digestate suspension to below 4.5 using the electrochemical reactions and enhance phosphorus solubilisation from the waste; ii) change the configuration of the electrodialytic cell from 3- to 2-chambers; and iii) stir the sample to shorten the duration of the extraction.

RESULTS: Results show that the acidification of digestate by the electrochemical reactions was effective to enhance phosphorus extraction yield. Three-chamber electrodialytic experiments enabled the removal of heavy metals from digestate, producing phosphorus-rich solutions with a low level of metals. This resulted in the production of high quality fertiliser which can be used for agricultural applications. The modification of electrodialytic cell set-up from 3-chamber to 2-chamber did not result in an increase of the phosphorus extraction yields nor did it contribute to the removal of metals from the liquid phase of digestate. The reduction of the hydraulic retention time of electrodialytic extraction of phosphorus from $16 \mathrm{~d}$ to $9 \mathrm{~d}$ was attained by the use of stirring and by the electrodialytic acidification.

CONCLUSIONS: The increase of phosphorus recovery was accomplished. $90 \%$ of phosphorus was successfully extracted from digestate and transformed into struvite.

\section{Keywords}

Electrodialytic process; Heavy metals; Municipal solid waste; Phosphorus; Struvite.

\section{Introduction}

The decline of phosphate rock reserves used by the fertiliser industry has led to the search of alternative sources of phosphorus. Several waste streams have been pointed out as potential secondary 
sources from where phosphorus can be recovered. ${ }^{1}$ Municipal solid waste (MSW) contains up to $30 \%$ $-50 \%$ of organic waste, ${ }^{2}$ the majority of which food scraps rich in phosphorus (up to $4.0 \mathrm{~g} \mathrm{~kg}^{-1}$, dry matter). ${ }^{3}$ The sludge resulting from the treatment by anaerobic digestion (herein referred to as "digestate") of these organic wastes is a potential secondary source of phosphorus, provided no contaminants are present. Annually, around 56 Mtonnes of digestate are produced in Europe, ${ }^{2}$ and this figure will likely increase in the future. Depending on the feedstock to the anaerobic digester, the digestate has two main final destinations: (i) application in agriculture (usually after composting) due to its high available fraction of nitrogen and phosphorus; or (ii) landfilling.

Use of digestates in agriculture is only possible when the levels of contaminants are low. Most large scale anaerobic digestors for MSW handle a mix of different organic material, including mixed and/or unsorted waste where the levels of contaminants are higher than in the pure fractions. Such digestate usually fails to meet the criteria for agriculture application and large amounts end up landfilled or are used in non-agricultural applications where their nutrient content is not valorised. ${ }^{2}$ In either case, the nutrients are lost. This practice is contradictory to the circular economy principles, because while the global reserves of phosphate rock fastly decline, a potential source of phosphorus is not correctly recycled and/or utilised. This framework inspired the current work, in which the recovery of phosphorus from digestate is addressed. The main challenge in the valorisation of digestate is the ability to extract phosphorus while leaving behind the contaminants. Amongst the contaminants, heavy metals are of special concern due to their potentially negative effects in soils and crops. ${ }^{4}$

Among extraction techniques, the electrodialytic (ED) process is pointed out as a feasible technique that has been used to extract phosphorus from a few waste streams: i) wastewater, ${ }^{5}$ ii) sewage sludge ${ }^{6}$ and their ashes ${ }^{7-11}$ and iii) MSW digestate. ${ }^{12}$ The principle of this technology has been explained elsewhere. ${ }^{13}$ Briefly, during the ED process, a low-intensity electric current crosses a water-saturated waste promoting the transport of the soluble charged ions towards the electrode of opposite charge. 
Since anions are attracted to the anode and cations to the cathode, ED promotes the simultaneous extraction and build-up of anions and cations into separate chambers. In a more detailed analysis, the extraction of phosphorus using the ED technique involves different processes. In the first stage, phosphorus dissolves from the solid waste particles into the solution. The phosphorus concentration in the solution increases until the equilibrium concentration is reached. At that point, dissolution and the precipitation rates are equal, and the concentration in solution does not change. In the second phase, dissolved phosphorus ions (negatively-charged) migrate across the water-saturated waste in the direction of the anode, driven by the electric field. Finally, in the third phase the phosphorus is driven across the inner pores of the anion-exchange membrane, reaching the anode-side chamber. When phosphorus is removed from the waste chamber, the dissolution equilibrium is disturbed, and additional phosphorus dissolves from the waste. This is again followed by migration of dissolved phosphorus towards anode. The dissolution and transport processes occur continuously, so the equilibrium is ideally not reached. This mechanism means that ED process can potentially remove more phosphorus than other extraction methods. Eventually all phosphorus dissolves from the waste and moves into anode-side chamber.

In a previous work, $42 \%$ of the total phosphorus present in digestate was extracted using the ED process. ${ }^{12}$ Extracted phosphorus was subsequently transformed into a struvite-based fertiliser. Even though this earlier work highlighted the potential of digestate from MSW to serve as a secondary source of phosphorus, there were still several problems that needed to be tackled, namely the low extraction yields (more than $50 \%$ of phosphorus in the waste was not recovered), the presence of heavy metal contaminants in the fertiliser $(\mathrm{Cd}, \mathrm{Pb}$, and $\mathrm{Cu}$ were eliminated, but $\mathrm{Zn}$ levels ranged 0.6 $\left.1.4 \mathrm{~g} \mathrm{~kg}^{-1}\right)$, and the high hydraulic retention time required for the extraction (16 d).

The main purpose of the current work is to propose and test several modifications to the ED extraction in order to improve the recovery of phosphorus from digestate. The targets are three-fold: i) achieve 
higher phosphorus extraction yields from this waste; ii) improve the quality of the fertiliser produced by decreasing the level of contaminants; and iii) reduce hydraulic retention time to allow for smaller system footprints and lower investment costs.

\section{Materials and methods}

\subsection{Strategies proposed for improving the recovery of phosphorus from digestate}

The strategies proposed herein to tackle potential transport-related issues are: a) decrease the distance phosphorus needs to travel driven by the electric field through stirring of the digestate suspension and; b) avoid the transport of phosphorus across the anion-exchange membrane by changing the configuration of the ED cell. The strategy proposed herein to tackle dissolution-related constrains are to lower the $\mathrm{pH}$ within the waste chamber through the electrochemical reactions taking place at to enhance dissolution of the digestate. Figure 1 summarises the three strategies that were applied in the present work according to the specific targets established.

(Fig. 1 here)

\subsection{Testing the strategies}

\subsubsection{Digestate}

Digestate was collected from an integrated center for treatment and recovery of municipal solid waste located in Portugal. In this facility, the organic fraction of municipal solid waste is firstly mechanically separated from mixed waste, then submitted to anaerobic digestion and finally composted. The sample 
was collected after centrifugation of the sludge from the anaerobic digester. The sample was then transported to the laboratory under refrigerated conditions $\left(<4^{\circ} \mathrm{C}\right)$, dried upon arrival $\left(105^{\circ} \mathrm{C}, 24 \mathrm{~h}\right)$, grounded $(<1 \mathrm{~mm})$ and stored in closed containers until use in extraction experiments.

The characteristics of digestate are shown in Table 1. Digestate presented a slightly alkaline $\mathrm{pH}$ and a total phosphorus content of about $0.8 \%$.

(Table 1 here)

\subsubsection{ED experiments to extract phosphorus from digestate}

Two different set-ups (depicted in Fig. 2) were used to extract phosphorus from digestate. The 3chamber set-up (Fig. 2a) aimed at moving phosphorus out from waste chamber into anode-side chamber and at moving metal cations out from waste chamber into cathode-side chamber. The 2chamber set-up (Fig. 2b) aimed at moving metal cations out of waste chamber into cathode-side chamber, leaving solubilised phosphorus in waste chamber.

(Fig. 2 here)

The ED cells used were cylindrical, made of Plexigas and with an internal diameter of $8 \mathrm{~cm}$. Waste chamber had a length of $10 \mathrm{~cm}$ and contained a suspension of $35 \mathrm{~g}$ of digestate in $350 \mathrm{~mL}$ of distilled water $\left(\mathrm{L}: \mathrm{S}=10 \mathrm{~mL} \mathrm{~g}^{-1}\right)$. The anode- and cathode-side chambers were $5 \mathrm{~cm}$ long and contained electrolyte solutions of $0.01 \mathrm{M} \mathrm{NaNO}_{3}$ (adjusted to $\mathrm{pH}<2$ with $\mathrm{HNO}_{3}$ ). 
Electrodes consisted of rods of platinum coated titanium, $3 \mathrm{~mm}$ in diameter and $5 \mathrm{~cm}$ long (from Permascand). In the 3-chamber set-up the cathode was placed in the cathode-side chamber and the anode in the anode-side chamber. In the 2-chamber set-up the cathode was placed in the cathode-side chamber (as in the 3-chamber set-up) but the anode was placed directly in the waste chamber. Plastomec pumps were used to recircule the electrolytes between the electrode compartments and glass flasks, to eliminate the gases released during the electrode reactions and avoid the formation of a layer with a high concentration of ions close the membranes. ${ }^{14}$

A physical separation between waste chamber and the cathode-side chamber was made using a cation exchange membrane (CR67 HUY N12116B) and only for the 3-chamber set-up an anion exchange membrane (204 SZRA B02249C) was used to separate the waste chamber from the anode-side chamber.

Eight ED experiments were carried out. Four using the 3-chamber set-up with a duration of 3, 7, 9 and $11 \mathrm{~d}$ and the other four using the 2-chamber set-up for the same period. In all experiments, a constant current intensity of $50 \mathrm{~mA}$ was applied (Hewlett Packard E3612A) and the suspension of digestate was continuously mixed using a VWR VOS 14 stirrer (H500 rpm).

During the ED experiments, $\mathrm{pH}$ and electric conductivity were measured daily in the digestate suspension by electrodes. $\mathrm{pH}$ was also measured in the cathode-side chamber since its $\mathrm{pH}$ value should be maintained below 2 in order to avoid the formation of metal hydroxides precipitates nearby the cation exchange membrane (which would hinder ion transport through the ED cell). ${ }^{14}$ A record of the current intensity and voltage drop across the cell was done. In addition, some samples were collected from waste chamber when an alteration of waste suspension $\mathrm{pH}$ was noted, in order to determine phosphorus speciation during ED process.

At the end of the ED experiments, the volume of electrolytes was recorded and the digestate 
suspension was filtered using quantitative filter paper. The volume of liquid phase of digestate was registered and the solid phase was dried in an oven at $105^{\circ} \mathrm{C}$, overnight. Ion exchange membranes and electrodes were immersed in $1 \mathrm{M}$ and $5 \mathrm{M} \mathrm{HNO}_{3}$, respectively, during $24 \mathrm{~h}$, to release any elements attached to them. Contents of phosphorus, calcium, magnesium, iron, aluminium and heavy metals $(\mathrm{Cd}, \mathrm{Cr}, \mathrm{Cu}, \mathrm{Ni}, \mathrm{Pb}$ and $\mathrm{Zn}$ ) were quantified in solid (after its crushing in a mortar) and liquid phase of digestate and in filtered ( $0.45 \mu \mathrm{m}$ syringe filter) electrodes and ion exchange membranes cleaning solutions, according to the procedure described in section 2.5.

\subsubsection{Phosphorus extraction yield}

In the 3-chamber experiments, the phosphorus extraction yield was calculated as the mass of phosphorus found in the anolyte at the end of experiment divided by the total mass of phosphorus found in the different parts of ED cell at the end of the experiment. In the 2-chamber experiments, the phosphorus extraction yield was based in the relation between the mass of phosphorus found in liquid phase of digestate and the total mass found in different parts of ED cell at the end of the experiment.

\subsection{Modelling of phosphorus speciation during 2-chamber ED experiments}

To evaluate the phosphorus speciation during 2-chamber ED experiments, the data of chemical composition and $\mathrm{pH}$ of the liquid phase of digestate was used in the software Visual Minteq 3.1. The calculations assumed a temperature of $25^{\circ} \mathrm{C}$ and the ionic strength was calculated by the software. 


\subsection{Phosphorus transformation into struvite}

Chemical precipitation of struvite was made in order to promote the recovery of phosphorus from the digestate into a solid form that can be used for agriculture applications. The anolyte solutions from the 3-chamber experiments and the liquid phase of digestate solutions from the 2-chamber experiments, with duration of 7, 9 and $11 \mathrm{~d}$, were used for phosphorus precipitation as struvite, following the procedure described in Oliveira et al. ${ }^{12}$ Briefly, while the solutions were stirring, it was added $\mathrm{MgCl}_{2} \cdot 6 \mathrm{H}_{2} \mathrm{O}$ and $\mathrm{NH}_{4} \mathrm{Cl}$ in a molar ratio $\mathrm{Mg}: \mathrm{N}: \mathrm{P}$ of $2: 2: 1$, and the $\mathrm{pH}$ was raised to 9 using $5 \mathrm{M}$ $\mathrm{NaOH}$. After $60 \mathrm{~min}$ of reaction, the struvite-suspension was filtered through $0.45 \mu \mathrm{m}$ membrane filter and the struvite-precipitates were dried at $50{ }^{\circ} \mathrm{C}$ for $48 \mathrm{~h}$. The precipitates obtained were analysed by X-ray diffraction (XRD, Rigaku Geigerflex (JP) with a Cu anode, operating at $20 \mathrm{kV}$ and $40 \mathrm{~mA}$ ) and scanning electron microscopy coupled with energy dispersion spectroscopy (SEM-EDS) using Hitachi SU-70 equipped with EDS - Bruker. The contents of phosphorus, calcium, magnesium, iron, aluminium and heavy metals were analysed in the precipitates.

\subsection{Analytical methods}

The digestate's $\mathrm{pH}$ and electric conductivity were measured using Radiometer electrodes after $1 \mathrm{~h}$ or $30 \mathrm{~min}$ agitation, respectively, of a suspension of $5.0 \mathrm{~g}$ of dry sample in $12.5 \mathrm{~mL}$ of distilled water. Total contents of phosphorus, calcium, magnesium, iron, aluminium and heavy metals in digestate, solid samples from ED experiments and struvite precipitates were measured in triplicate after a pretreatment described in Danish Standard DS259: $1.0 \mathrm{~g}$ of dry sample was placed into a schott flask and $20.0 \mathrm{~mL}$ of $1: 1 \mathrm{HNO}_{3}$ was added. The flasks were heated in an autoclave at $200 \mathrm{kPa}\left(120^{\circ} \mathrm{C}\right)$ during $30 \mathrm{~min}$. Then the samples were filtered by vacuum through a $0.45 \mu \mathrm{m}$ filter and diluted to $50 \mathrm{~mL}$. A Varian 720-ES ICP-OES (Inductively Coupled Plasma-Optical Emission Spectrometry) was used to 
quantify the elemental concentration in pre-treated samples as well as in all samples from ED and precipitation experiments.

\section{Results and discussion}

\subsection{Phosphorus extraction yields}

\subsubsection{Development of $\mathrm{pH}$ during the ED process}

Low extraction yields are related to either the dissolution phase or to the transport phases. The low dissolution of phosphorus compounds, especially at the natural $\mathrm{pH}$ of the digestate (slightly alkaline, 7.7 - 7.8) can be addressed by acidification of the digestate. In the current work, the strategy proposed was to enhance solubilisation by lowering the $\mathrm{pH}$ of the digestate suspension to below 4.5 , using the electrochemical reactions occurring during ED. The effect of the electrochemical reactions on the acidification of digestate suspension was assessed by measuring $\mathrm{pH}$ in the digestate suspension during the extraction (Fig. 3). At the beginning of the experiments, the $\mathrm{pH}$ in the digestate suspensions ranged 7.4 - 8.1. During the experiments, the $\mathrm{pH}$ decreased, and the decrease was faster during the 2-chamber experiments than during the 3-chamber experiments: a pH $3-3.5$ was registered after $3 \mathrm{~d}$ in the 2 chamber, while in the 3-chamber similar $\mathrm{pH}$ values were only reached after $6 \mathrm{~d}$ or $7 \mathrm{~d}$. In addition, for the same experimental time, the $\mathrm{pH}$ of the digestate suspension was 1-3 units below in 2-chamber experiments, when compared to the 3-chamber experiments. Acidification in the 2-chamber ED cell occurs due to the generation of $\mathrm{H}^{+}$by the half-reaction taking place at the anode: $2 \mathrm{H} 2 \mathrm{O} \rightarrow \mathrm{O}_{2}(\mathrm{~g})+$ $4 H^{+}+4 e^{-}$(Eq. 1). Whereas, in the 3-chamber experiments, the same reaction takes place at the surface of the anion-exchange membrane (phenomena denominated as water splitting ${ }^{15,16}$ ) separating waste chamber and anode-side chamber, leading to acidification of the waste inside waste chamber. This explains the different acidification rates. In both ED cell set-ups, acidification of the digestate 
suspension in the waste compartment was successfully achieved by the electrochemical reactions alone, without the need for adding external acids. Overall, an identical development of $\mathrm{pH}$ was observed over time in all experiments which indicates a good repeatability and robustness of the ED experiments. In the 2-chamber experiments, the decrease in $\mathrm{pH}$ was accompanied by a progressive increase of the electric conductivity (Fig. 3). This was mainly due to the solubilisation of ions from the digestate and also to the addition of $\mathrm{H}^{+}$ions directly into the waste compartment due to water electrolysis at the anode (Eq. 1). Oppositely, in the 3-chamber experiments, a decrease of the electric conductivity in the digestate suspension was registered. During the first $3 \mathrm{~d}$, the electric conductivity decreased drastically and then it remained constantly low, at around $0.4 \mathrm{mS} \mathrm{cm}^{-1}$, until the end of ED process. This is explained by the electromigration of the dissolved anions, such as phosphorus, out of waste chamber into the anode-side chamber and of cations, such as heavy metals into the cathode-side chamber.

(Fig. 3 here)

\subsubsection{Comparison of 2- and 3-chamber ED cell}

Figure 4 shows the distribution of phosphorus (in percentage) in the ED cell at the end of the experiments. Overall, in the 2-chamber experiments phosphorus was mostly $(86 \%)$ in the waste chamber (liquid phase: $70 \%$; solid phase $16 \%$ ), while a smaller percentage (14\%) was in the cathode chamber. Oppositely, in the 3-chamber experiments, less than $3 \%$ of phosphorus was found in the liquid phase of digestate, and most phosphorus in solution was transported out of waste chamber into the anode-side chamber ( $89 \%)$, as intended (to separate phosphorus from the digestate). In both setups a residual amount of phosphorus (16\% in the 2 -chamber and $9 \%$ in the 3 -chamber) was not 
dissolved during the extraction and remained in the solid phase of the original material.

Solubilisation of phosphorus occurred since the very beginning of the ED process, with more than half the phosphorus being extracted in the first $3 \mathrm{~d}$ : $54 \%$ in the 3-chamber experiment (at pH $=5.8$ ) and $58 \%$ in the 2 -chamber experiment (at $\mathrm{pH}=2.8$ ). For both 2 - and 3-chamber experiments, the phosphorus extraction yields increased as the $\mathrm{pH}$ decreased.

(Fig. 4 here)

The extraction of phosphorus did not evolve after $9 \mathrm{~d}$, with the values for $9 \mathrm{~d}$ and $11 \mathrm{~d}$ being identical. Overall, after $9 \mathrm{~d}$ a higher amount of phosphorus was extracted from the digestate in the 3-chamber experiments $(90 \%)$ than in the 2 -chamber experiments $(71 \%)$. This result was not anticipated, since in other studies comparing both set-ups (to extract phosphorus from wastes), the 2-chamber performed better. ${ }^{8,17}$

A pH range of $2.5-3.0$ seems to be favourable to extract phosphorus from the digestate using a 3chamber ED cell (Fig. 4b). In a 2-chamber ED cell, a lower pH 1 - 2 favoured the extraction. A suitable $\mathrm{pH}$ range of 2.5 - 3.0 was attained after $7 \mathrm{~d}$ in the 3-chamber experiments; however, phosphorus continued to be extracted until day 9. This indicates that the phosphorus extraction from digestate did not occur immediately and there is a gap between the time an adequate $\mathrm{pH}$ range for the extraction is reached and the time when no more phosphorus is extracted.

Based on the results above, lowering the $\mathrm{pH}$ of digestate suspension to below 4.5 (previously found in Oliveira et al. ${ }^{12}$ ) by acidification of the digestate suspension using the electrochemical reactions is an important contributor to the enhancement of phosphorus solubilisation, which consequently increases phosphorus extraction yields. 
A relevant detail for the 2-chamber experiment is that phosphorus started to appear in the cathode-side chamber after $7 \mathrm{~d}$, reaching $14 \%$ of total phosphorus after $11 \mathrm{~d}$ (Fig. 4a). This result indicates that prolonging the 2-chamber experiments after the time where the maximum phosphorus extraction yield was achieved ( $7 \mathrm{~d}$ ) meant a higher loss of phosphorus into the cathode-side chamber. Oppositely, for the 3-chamber experiments phosphorus was not transported to the cathode-side chamber (less than $0.2 \%)$.

\subsection{Distribution of heavy metals at the end of ED process}

Figure 5 presents the percentage of metals found in the different parts of the ED cell at the end of the extraction process. The cathode-side chamber included the catholyte, the cathode and the cation exchange membrane. In the 3-chamber experiments, the anolyte, the anode and the anion exchange membrane were grouped in the anode-side chamber.

Precipitation of struvite is induced from different chambers, depending on the cell set-up. In the 3chamber experiments, struvite is obtained from the anode-side chamber and in the 2-chamber experiment from the digestate suspension chamber. From the perspective of reducing the presence of potential contaminants in struvite it is important that these chambers do not contain heavy metals in solution at the end of the extraction step.

Overall, $70 \%$ to $90 \%$ of $\mathrm{Zn}$ and more than $40 \%$ of $\mathrm{Cd}$ and $\mathrm{Ni}$ were removed to the cathode-side chamber. $\mathrm{Cu}, \mathrm{Cr}$ and $\mathrm{Pb}$ mainly remained in the solid phase of the digestate (more than $60 \%$ ).

Regarding the presence of metals in the solutions that were further used to produce struvite, between $10 \%$ and $20 \%$ of the metals were found in the liquid phase in the 2-chamber experiments. In the 3chamber experiments only a residual amount of metals (less than $4 \%$ ) were found in the anode-side chamber. Furthermore, the presence of $\mathrm{Zn}$ in the anode-side chamber (seen in Oliveira et al. ${ }^{12}$ ) was 
avoided in the current work. The reduction of the experimental time from $16 \mathrm{~d}$ (previous reported results, ${ }^{12}$ ) to $11 \mathrm{~d}, 9 \mathrm{~d}$ or $7 \mathrm{~d}$ (current work) and the final $\mathrm{pH}$ of digestate suspension from about 4.5 (previous reported results ${ }^{12}$ ) to about 2.5 - 3.0 may explain the low mobilisation of $\mathrm{Zn}$ into the anodeside chamber.

(Fig. 5 here)

\subsection{Modelling phosphorus speciation}

The unwanted transport of phosphorus into the cathode-side chamber seen during the 2-chamber experiments was not ideal, because all the metals cations that are contaminants in the fertiliser are also removed into this chamber. Phosphorus in the cathode-side chamber is therefore considered to be lost from the point of view of producing a fertiliser. Transport of phosphorus into the cathode-side occurs if positively-charged phosphorus species are formed. So, a deeper analysis was carried out to understand how the other elements present in the waste suspension affect the formation of positively charged phosphorus-species, using the modelling software MINTEQ. This analysis was not performed for the 3-chamber experiments because the presence of phosphorus in the cathode-side chamber was not observed and the charged phosphorus ions were mostly moved into the anode-side chamber. Table 2 shows the probable speciation of phosphorus at different $\mathrm{pH}$ values considering the chemical species measured in the waste suspension during the 2-chamber experiments. At lower $\mathrm{pH}$ values $(<3)$, in addition to the existence of negative $\left(\mathrm{H}_{2} \mathrm{PO}_{4}{ }^{2-}\right)$ and neutral $\left(\mathrm{H}_{3} \mathrm{PO}_{4}\right)$ phosphorus forms, occurs also the complexation of phosphorus with $\mathrm{Fe}^{3+}, \mathrm{Ca}^{2+}$ and $\mathrm{Al}^{3+}$ in solution, forming positively-charged species: $\mathrm{FeHPO}_{4}{ }^{+}, \mathrm{FeH}_{2} \mathrm{PO}_{4}{ }^{+2}, \mathrm{CaH}_{2} \mathrm{PO}_{4}{ }^{+}$and $\mathrm{AlHPO}_{4}{ }^{+}$. The presence of these positively-charged forms of phosphorus explains the phosphorus found in the cathode-side chamber. 
(Table 2 here)

\subsection{Evaluation of struvite quality}

\subsubsection{Structure and elemental composition of struvite}

Figure 6 shows the XRD pattern of the precipitates harvested during the struvite-production stage. For the 3-chamber experiments, a crystalline phase showed up, matching the profile (position and intensity of the peaks) of the struvite standard. No extra/minor phases were identified in the XRD pattern, consistent with a precipitate of pure struvite. XRD results for the precipitates harvested from the 2chamber experiments indicates that there were no crystalline phases for the $7 \mathrm{~d}$ and $11 \mathrm{~d}$ experiments, so struvite crystals were not formed in these two experiments. In the $9 \mathrm{~d}$-experiment, there was a crystalline phase consistent with struvite; however, there was background noise affecting the peak definition, indicating that impurities were present. Le Corre et al ${ }^{18}$ reported that as the calcium concentration in solution increases, the struvite formation can be hindered, either due to calcium competing for the phosphate ions or because this element interferes with the crystallisation of struvite. There were large amounts of calcium ions present in the solutions the 2-chamber experiments (Table 3), especially for $7 \mathrm{~d}$ and for $11 \mathrm{~d}$, explaining why struvite formation was strongly hindered in these two experiments. In the 3-chamber experiments, there was almost no calcium in solution, likely because this cation has been moved towards the cathode-side chamber.

(Table 3 here) 
The EDS spectrums of the precipitates are shown in Fig. 7. The major elements were magnesium and phosphorus, consistent with struvite. For the case of 2-chamber experiments, a distinctive peak for calcium was also identified, while struvite peaks were still detectable. The calcium peak identified on precipitates obtained from the $7 \mathrm{~d}$ and $11 \mathrm{~d}$ - liquid phase solutions was higher than the obtained at $9 \mathrm{~d}$, which likely led to the formation of an amorphous substance (such as calcium phosphates) in place of struvite (Fig. 6a: $7 \mathrm{~d}$ and $11 \mathrm{~d}$ ).

(Fig. 6 here)

(Fig. 7 here)

\subsubsection{Assessment of the struvite fertiliser for application in agriculture}

Up to $98 \%$ of phosphorus in solution after the extraction stage was recovered in solid form in the struvite-inducing experiments. The percentage of phosphorus in the precipitates obtained from the 3chamber experiments is almost twice what was measured in the precipitates from the 2-chamber experiments (Table 4). Additionally, the precipitates obtained from 2-chamber experiments contained levels of $\mathrm{Pb}, \mathrm{Cd}$ and $\mathrm{Zn}$ above the Portuguese legal limits for fertilisers, which means they cannot be used in agriculture. Contrarily, the precipitates obtained from the 3-chamber experiments contained low level of metals $(\mathrm{Cr}, \mathrm{Pb}$ and $\mathrm{Zn})$, which did not exceed the limits of metal contents established by the Portuguese legislation for fertilisers (Table 4), which highlights their lower level of contaminants 
and superior quality.

(Table 4 here)

\subsection{Hydraulic retention time of ED extraction of phosphorus}

The utilisation of a stirrer in the waste chamber and the acidification of digestate suspension below $\mathrm{pH}$ 4.5 were the strategies proposed to reduce the hydraulic retention times. In a previous work (Oliveira et al. ${ }^{12}$ ) it took $16 \mathrm{~d}$ to extract about $130 \mathrm{mg}$ of phosphorus using a 3-chamber ED cell identical to the one used in the current work, but in a stationary set-up (without stirring). Table 5 compares the amount of phosphorus extracted in the previous and in the current work, normalised for the electric charges passed during the experiments (expressed in Coulomb, C).

(Table 5 here)

A similar amount of phosphorus was found at the end of the 3-day stirred ED experiment and the stationary experiment; however, twice the amount of phosphorus was removed per unit of Coulomb, and only $3 \mathrm{~d}$ were necessary, instead of $16 \mathrm{~d}$. This result demonstrates the positive influence of the utilisation of a stirrer on the reduction of the hydraulic retention time of ED process. The other stirred ED experiments (7,9 and $11 \mathrm{~d})$ showed that as the extraction time proceeded it became ever more difficult to extract the remaining phosphorus, since the amount of phosphorus extracted per unit charge passing through the cell decreases. Eventually the amount phosphorus extracted is kept constant, even though electric charges are still being passed through the cell, as was seen between $9 \mathrm{~d}$ and $11 \mathrm{~d}$. These 
results reveal that the hydraulic retention time of ED extraction of phosphorus from digestate can be reduced by $44 \%$ (from $16 \mathrm{~d}$ to $9 \mathrm{~d}$ ).

\section{Conclusions}

In the present work, the effects of modifications to the ED process to improve the recovery of phosphorus from anaerobically digested organic fraction of municipal solid waste were evaluated. Under the experimental conditions tested here, the following conclusions were drawn:

i) the acidification of digestate to a $\mathrm{pH}$ below 4.5 using the electrochemical reactions occurred during ED process led to an enhancement of phosphorus extraction yield.

ii) the ED extraction of phosphorus from digestate is higher for the 3-chamber ED cell set-up. The proposed strategy of changing the configuration of the ED cell to 2-chamber did not contribute to the increasing of phosphorus extraction yield.

iii) A low presence of heavy metals in phosphorus rich solutions from the 3-chamber ED experiments, results in the production of a high quality struvite that complies with regulatory limit values to be used as fertiliser in agriculture. Opposedely, in the 2-chamber ED experiments, the ED process was not effective for removing heavy metals and a contaminated material was produced, that failed the limit values for agricultural application.

iv) the utilisation of a stirrer in the waste compartment and the acidification of digestate promoted by the electrochemical reactions were important contributors to the reduction of the hydraulic retention time of ED extraction of phosphorus.

Overall, the objectives proposed in the current work were accomplished: i) the phosphorus extraction yield from digestate was considerably enhanced; ii) the harvested precipitates have high quality to be applied as fertiliser and; iii) the hydraulic retention time of ED extraction of phosphorus was 
substantially reduced.

\section{Acknowledgements}

The authors would like to thank Sabrina Hvid for carrying out ICP analyses. This work has been funded by Portuguese National Funds through FCT - Portuguese Foundation for Science and Technology under CERNAS (UID/AMB/00681/2013). Celia Dias-Ferreira and Verónica Oliveira have been funded through FCT "Fundação para a Ciência e para a Tecnologia" by POCH - Programa Operacional Capital Humano within ESF - European Social Fund and by national funds from MCTES (SFRH/BPD/100717/2014; SFRH/BD/115312/2016). Joana L. Rocha has been funded by project 0340-SYMBIOSIS-3-E co-funded by FEDER “Fundo Europeu de Desenvolvimento Regional” through Interreg V-A España-Portugal (POCTEP) 2014-2020.

\section{References}

1. Karunanithi R, Szogi AA, Bolan N, Naidu R, Loganathan P, Hunt PG, Vanotti MB, Saint CP, Ok YS and Krishnamoorthy S, Phosphorus recovery and reuse from waste streams. Adv. Agron. 131: $173-250$ (2015).

2. European Commission. End-of-waste criteria for Biodegradable waste subjected to biological treatment (compost \& digestate): Technical proposals Final Report December 2013. (2014).

3. Kalmykova Y and Fedje KK, Phosphorus recovery from municipal solid waste incineration fly ash. Waste Manag. 33: 1403-1410 (2013).

4. Singh J and Kalamdhad AS, Effects of heavy metals on soil, plants, human health and aquatic life. Int. J. Res. Chem. Environ. 1: 15-21 (2011).

5. Ebbers B, Ottosen LM and Jensen PE, Electrodialytic treatment of municipal wastewater and 
sludge for the removal of heavy metals and recovery of phosphorus. Electrochim. Acta 181: 90-99 (2015).

6. Guedes P, Magro C, Couto N, Mosca A and Mateus EP, Potential of the electrodialytic process for emerging organic contaminants remediation and phosphorus separation from sewage sludge. Electrochim. Acta 181: 109-117 (2015).

7. Guedes P, Mateus EP, Almeida J, Ferreira AR, Couto N and Ribeiro AB, Electrodialytic treatment of sewage sludge: Current intensity influence on phosphorus recovery and organic contaminants removal. Chem. Eng. J. 306: 1058-1066 (2016).

8. Guedes P, Couto N, Ottosen LM, Kirkelund GM and Mateus E, Valorisation of ferric sewage sludge ashes: Potential as a phosphorus source. Waste Manag. 52: 193-201 (2016).

9. Guedes P, Couto N, Ottosen LM and Ribeiro AB, Phosphorus recovery from sewage sludge ash through an electrodialytic process. Waste Manag. 34: 886-892 (2014).

10. Viader RP, Jensen PE, Ottosen LM, Ahrenfeldt J and Hauggaard-Nielsen H, Electrodialytic extraction of phosphorus from ash of low-temperature gasification of sewage sludge. Electrochim. Acta 181: 100-108 (2015).

11. Viader RP, Jensen PE, Ottosen LM, Thomsen TP, Ahrenfeldt J and Hauggard-Nielsen H, Comparison of phosphorus recovery from incineration and gasification sewage sludge ash. Water Sci. Technol. 75: 1251-1260 (2017).

12. Oliveira V, Labrincha $\mathrm{J}$ and Dias-Ferreira $\mathrm{C}$, Extraction of phosphorus and struvite production from the anaerobically digested of organic fraction of municipal solid waste. J. Environ. Chem. Eng. 6: 2837-2845 (2018).

13. Guedes P, Couto N, Mateus EP and Ribeiro AB, Phosphorus Recovery in Sewage Sludge by Electrokinetic Based Technologies: A Multivariate and Circular Economy View. Waste and Biomass Valor 8: 1587-1596 (2017). 
14. Ebbers B, Ottosen LM and Jensen PE, Comparison of two different electrodialytic cells for separation of phosphorus and heavy metals from sewage sludge ash. Chemosphere 125: 122129 (2014).

15. Nystroem GM, Ottosen LM and Villumsen A, Acidification of Harbor Sediment and Removal of Heavy Metals Induced by Water Splitting in Electrodialytic Remediation. Sep. Sci. Technol. 40: $2245-2264$ (2005).

16. Ottosen LM, Hansen HK and Hansen CB, Water splitting at ion-exchange membranes and potential diferences in soil during electrodialytic soil remediation. J. Appl. Electrochem. 30: 1199-1207 (2000).

17. Ebbers B, Ottosen LM and Jensen PE, Comparison of two different electrodialytic cells for separation of phosphorus and heavy metals from sewage sludge ash. Chemosphere 125: 122129 (2015).

18. Le Corre KS, Valsami-Jones E, Hobbs P and Parsons SA, Impact of calcium on struvite crystal size, shape and purity. J. Cryst. Growth 283: 514-522 (2005).

19. Ministério da Economia. Decreto-Lei $n^{o} 103 / 2015$ de 15 de Junho. Diário da República, $1^{a}$ série - No 114 (In Portuguese). pp 3756-3788 (2015). 
Table 1 Characteristics of digestate (average \pm standard deviation).

\begin{tabular}{ll}
\hline Characteristic & Value \\
\hline $\mathrm{pH}$ & $7.67-7.71$ \\
Conductivity $\left(\mathrm{mS} \mathrm{cm}^{-1}\right)$ & $5.72 \pm 0.39$ \\
Total elements & \\
$\mathrm{P}\left(\mathrm{g} \mathrm{kg}^{-1}\right)$ & $7.53 \pm 0.48$ \\
$\mathrm{Ca}\left(\mathrm{g} \mathrm{kg}^{-1}\right)$ & $70.79 \pm 3.31$ \\
$\mathrm{Mg}\left(\mathrm{g} \mathrm{kg}^{-1}\right)$ & $10.94 \pm 0.78$ \\
$\mathrm{Al}\left(\mathrm{g} \mathrm{kg}^{-1}\right)$ & $8.16 \pm 0.56$ \\
$\mathrm{Fe}\left(\mathrm{g} \mathrm{kg}^{-1}\right)$ & $7.38 \pm 0.40$ \\
$\mathrm{Zn}\left(\mathrm{mg} \mathrm{kg}^{-1}\right)$ & $351.35 \pm 74.39$ \\
$\mathrm{~Pb}\left(\mathrm{mg} \mathrm{kg}^{-1}\right)$ & $158.57 \pm 14.58$ \\
$\mathrm{Cu}\left(\mathrm{mg} \mathrm{kg}^{-1}\right)$ & $148.13 \pm 21.90$ \\
$\mathrm{Cr}\left(\mathrm{mg} \mathrm{kg}^{-1}\right)$ & $34.01 \pm 2.06$ \\
$\mathrm{Ni}\left(\mathrm{mg} \mathrm{kg}^{-1}\right)$ & $29.30 \pm 3.56$ \\
$\mathrm{Cd}\left(\mathrm{mg} \mathrm{kg}^{-1}\right)$ & $1.22 \pm 0.05$ \\
\hline
\end{tabular}


Table 2 Phosphate speciation (\%) in the liquid phase of digestate during the 2-chamber experiments obtained from MINTEQ software $(*$ real/measured values).

\begin{tabular}{|c|c|c|c|c|c|c|c|c|}
\hline $\mathrm{pH}^{*}$ & $\begin{array}{l}\mathrm{P}]^{*} \\
\mathrm{mg} \mathrm{L}^{-1}\end{array}$ & $\mathrm{H}_{3} \mathrm{PO}_{4}$ & $\mathrm{HPO}_{4}{ }^{2-}$ & $\mathrm{H}_{2} \mathrm{PO}^{4-}$ & $\mathrm{FeH}_{2} \mathrm{PO}_{4}^{+2}$ & $\mathrm{FeHPO}_{4}{ }^{+}$ & $\mathrm{CaH}_{2} \mathrm{PO}_{4}^{+}$ & $\mathrm{AlHPO}_{4}^{+}$ \\
\hline 1.2 & 744 & 68 & - & 10 & 18 & 4 & 0.8 & 0.1 \\
\hline 1.3 & 734 & 65 & - & 11 & 18 & 5 & 0.9 & 0.2 \\
\hline 1.4 & 738 & 61 & - & 16 & 15 & 5 & 3 & 0.4 \\
\hline 1.4 & 665 & 58 & - & 14 & 19 & 6 & 2 & 0.2 \\
\hline 1.5 & 650 & 56 & - & 16 & 18 & 7 & 3 & 0.3 \\
\hline 1.6 & 785 & 55 & - & 19 & 15 & 7 & 2 & 0.6 \\
\hline 1.8 & 642 & 51 & - & 27 & 10 & 9 & 3 & 1 \\
\hline 1.9 & 700 & 41 & - & 31 & 9 & 13 & 2 & 3 \\
\hline 2.8 & 506 & 13 & - & 67 & 0.3 & 3 & 11 & 6 \\
\hline 2.9 & 484 & 10 & - & 70 & 0.2 & 3 & 11 & 6 \\
\hline 3.4 & 435 & 4 & 0.02 & 70 & 0.1 & 4 & 12 & 9 \\
\hline 3.6 & 390 & 2 & 0.04 & 79 & 0.02 & 1 & 14 & 3 \\
\hline 4.5 & 286 & 0.3 & 0.3 & 82 & - & 0.7 & 14 & 1 \\
\hline 5.0 & 194 & 0.1 & 0.9 & 84 & - & 0.9 & 11 & 1 \\
\hline 5.3 & 181 & 0.1 & 2 & 83 & - & 0.8 & 10 & 2 \\
\hline 5.4 & 192 & 0.04 & 2 & 81 & - & 1 & 10 & 1 \\
\hline 5.7 & 184 & 0.02 & 4 & 79 & - & 1 & 8 & 1 \\
\hline 7.4 & 31 & - & 49 & 21 & - & 0.02 & 0.4 & - \\
\hline
\end{tabular}


Table 3 Concentration of calcium in the solutions where struvite precipitation was promoted $\left(\mathrm{mg} \mathrm{L}^{-1}\right)$ obtained at the end of 2- and 3-chamber ED experiments with duration of $7 \mathrm{~d}, 9 \mathrm{~d}$ and $11 \mathrm{~d}$.

\begin{tabular}{lllllll}
\hline \multirow{2}{*}{ Element } & \multicolumn{3}{l}{ 2-chamber } & \multicolumn{5}{c}{ 3-chamber } \\
\cline { 2 - 7 } & $7 \mathrm{~d}$ & $9 \mathrm{~d}$ & $11 \mathrm{~d}$ & $7 \mathrm{~d}$ & $9 \mathrm{~d}$ & $11 \mathrm{~d}$ \\
\hline $\mathrm{Ca}\left(\mathrm{mg} \mathrm{L}^{-1}\right)$ & 600.8 & 271.6 & 641.3 & 1.4 & 3.2 & 3.7 \\
\hline
\end{tabular}


Table 4 Contents of phosphorus and heavy metals in the harvested precipitates from 2- and 3-chamber ED experiments with duration of 7, 9 and $11 \mathrm{~d}$ (average \pm standard deviation). In bold are the values outside the Portuguese legislation limits for application in agriculture (*Insufficient sample for replicates; ND: not detected).

\begin{tabular}{|c|c|c|c|c|c|c|c|}
\hline \multirow{3}{*}{ Elements } & \multicolumn{6}{|c|}{ ED cell set-up / duration } & \multirow{3}{*}{$\begin{array}{c}\text { Portuguese limits for } \\
\text { fertiliser } \\
\text { application }^{19}\end{array}$} \\
\hline & 2-chamber / & 2-chamber & 2-chamber & 3-chamber & 3-chamber & 3-chamber & \\
\hline & $7 \mathrm{~d}$ & $/ 9 \mathrm{~d}^{*}$ & $/ 11 \mathrm{~d}$ & $/ 7 \mathrm{~d}$ & $/ 9 \mathrm{~d}$ & $/ 11 \mathrm{~d}$ & \\
\hline $\mathrm{P}\left(\mathrm{g} \mathrm{kg}^{-1}\right)$ & $101.3 \pm 2.2$ & 103.6 & $101.9 \pm 0.3$ & $196.3 \pm 3.8$ & $171.3 \pm 6.2$ & $163.2 \pm 0.6$ & - \\
\hline $\mathrm{Cd}\left(\mathrm{mg} \mathrm{kg}^{-1}\right)$ & $\mathbf{2 . 4} \pm 0.05$ & 3.0 & $<0.02 \mathrm{mg} / 1$ & $<0.02 \mathrm{mg} / 1$ & $<0.02 \mathrm{mg} / 1$ & $<0.02 \mathrm{mg} / 1$ & 1.5 \\
\hline $\mathrm{Cr}\left(\mathrm{mg} \mathrm{kg}^{-1}\right)$ & $81.3 \pm 0.3$ & 117.0 & $113.8 \pm 0.1$ & $4.5 \pm 0.2$ & $3.3 \pm 0.3$ & $6.9 \pm 0.2$ & 150 \\
\hline $\mathrm{Cu}\left(\mathrm{mg} \mathrm{kg}^{-1}\right)$ & $72.9 \pm 0.7$ & 70.3 & $54.2 \pm 0.3$ & $<0.02 \mathrm{mg} / 1$ & $2.3 \pm 0.5$ & $<0.02 \mathrm{mg} / 1$ & 200 \\
\hline $\mathrm{Ni}\left(\mathrm{mg} \mathrm{kg}^{-1}\right)$ & $20.8 \pm 0.2$ & 11.9 & $6.3 \pm 0.1$ & ND & ND & $<0.02 \mathrm{mg} / 1$ & 100 \\
\hline $\mathrm{Pb}\left(\mathrm{mg} \mathrm{kg}^{-1}\right)$ & $\mathbf{2 8 8 . 0} \pm 0.1$ & 283.7 & $\mathbf{9 0 6 . 7} \pm 4.9$ & $7.6 \pm 0.3$ & $13.0 \pm 0.6$ & $13.6 \pm 0.1$ & 150 \\
\hline $\mathrm{Zn}\left(\mathrm{mg} \mathrm{kg}^{-1}\right)$ & $344.3 \pm 3.4$ & 427.0 & $\mathbf{8 5 9 . 4} \pm 6.8$ & $13.2 \pm 1.6$ & $22.9 \pm 1.0$ & $15.7 \pm 0.6$ & 500 \\
\hline
\end{tabular}


Table 5 Comparison of phosphorus extraction per unit of Coulomb in stationary and stirred ED experiments $(*$ reported in Oliveira et al. ${ }^{12}$ ).

\begin{tabular}{lcccc}
\hline ED cell & Duration & Phosphorus & Phosphorus removed per & Phosphorus \\
& $(\mathrm{d})$ & extracted & Coulomb & extraction yield \\
& & $(\mathrm{mg})$ & $\left(\mathrm{mg} \mathrm{C}^{-1}\right)$ & $(\%)$ \\
\hline Stationary $\left(^{*}\right)$ & 16 & 130 & 0.0094 & 43 \\
\hline Stirred & 3 & 142 & 0.0183 & 54 \\
& 7 & 215 & 0.0118 & 90 \\
& 9 & 236 & 0.0101 & 89 \\
\hline
\end{tabular}


a)
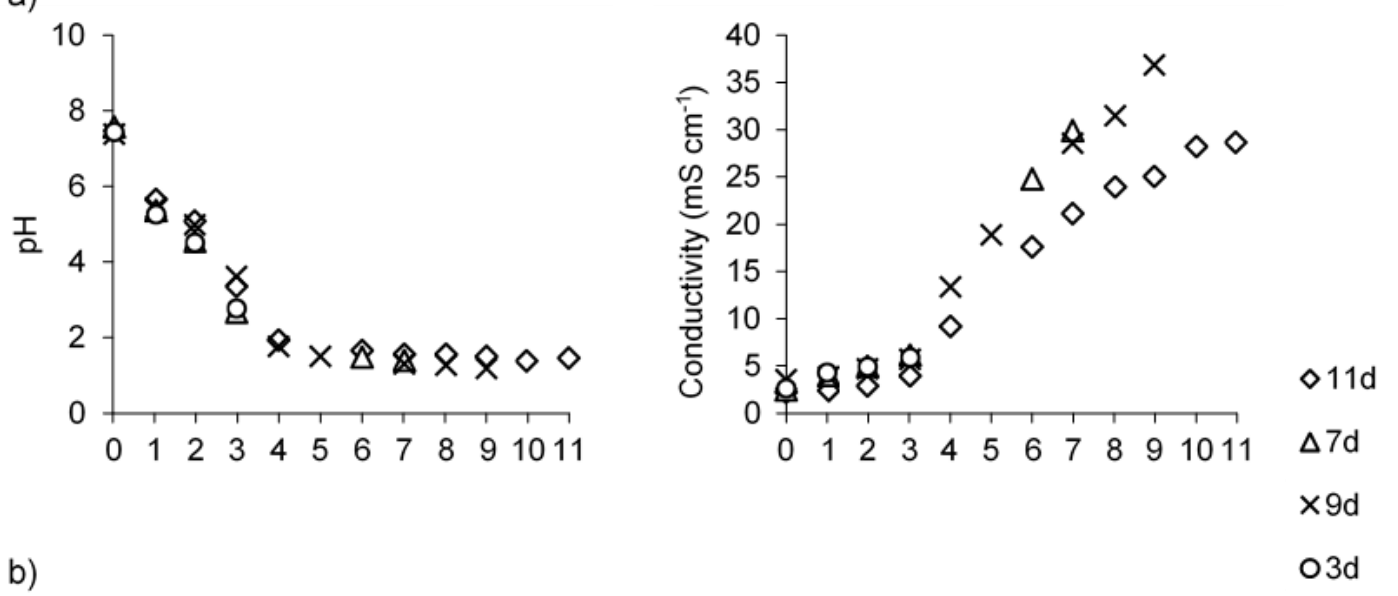

b)

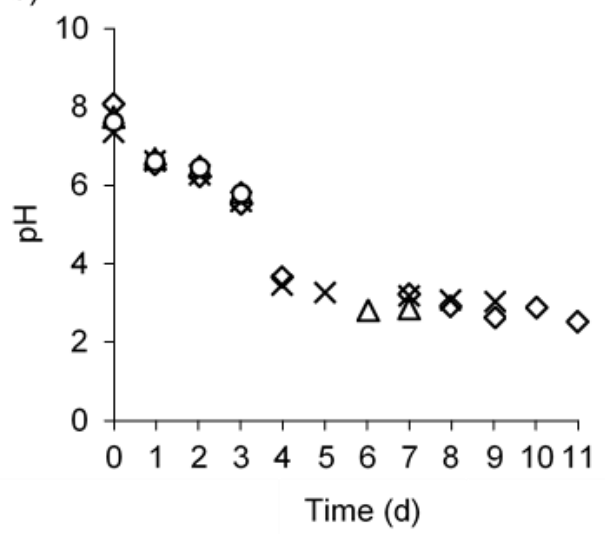

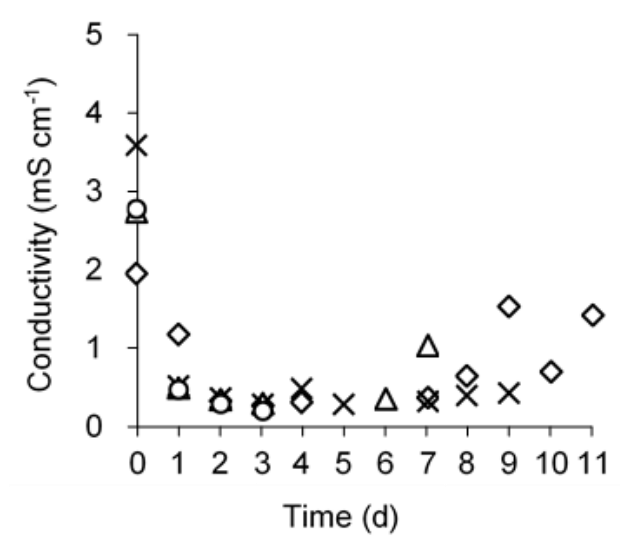

Fig. $3 \mathrm{pH}$ and electric conductivity measured in digestate suspension in a) 2-chamber and b) 3chamber ED experiments during 3, 7, 9 and $11 \mathrm{~d}$ 
a)

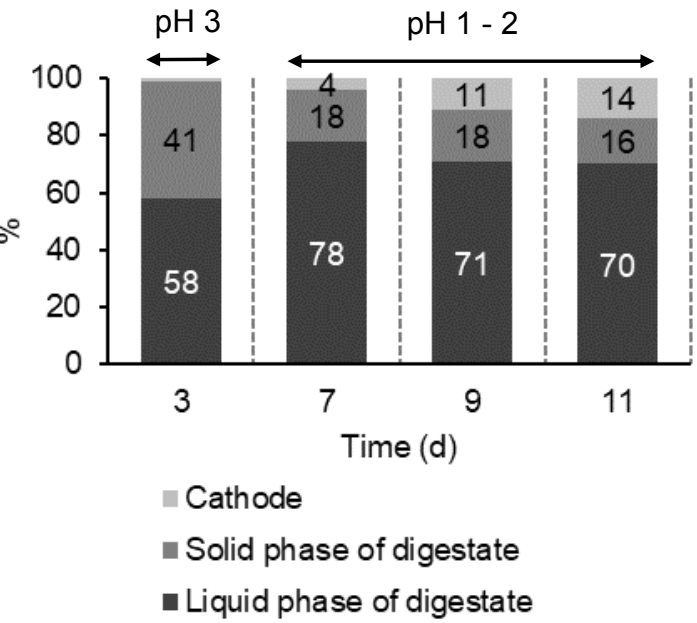

b)

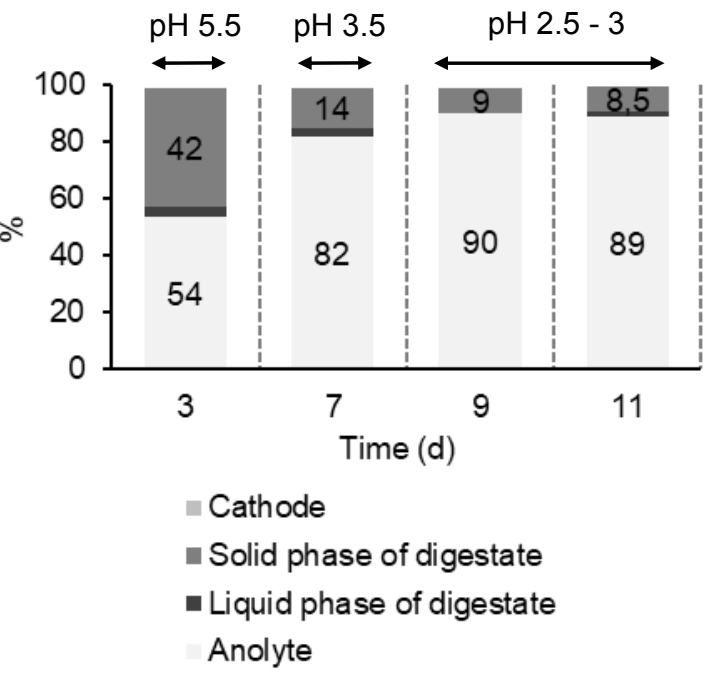

Fig. 4 Percentage of phosphorus found in anolyte, liquid and solid phase of digestate and cathodeside chamber at the end of a) the 2-chamber experiments and b) the 3-chamber experiments 


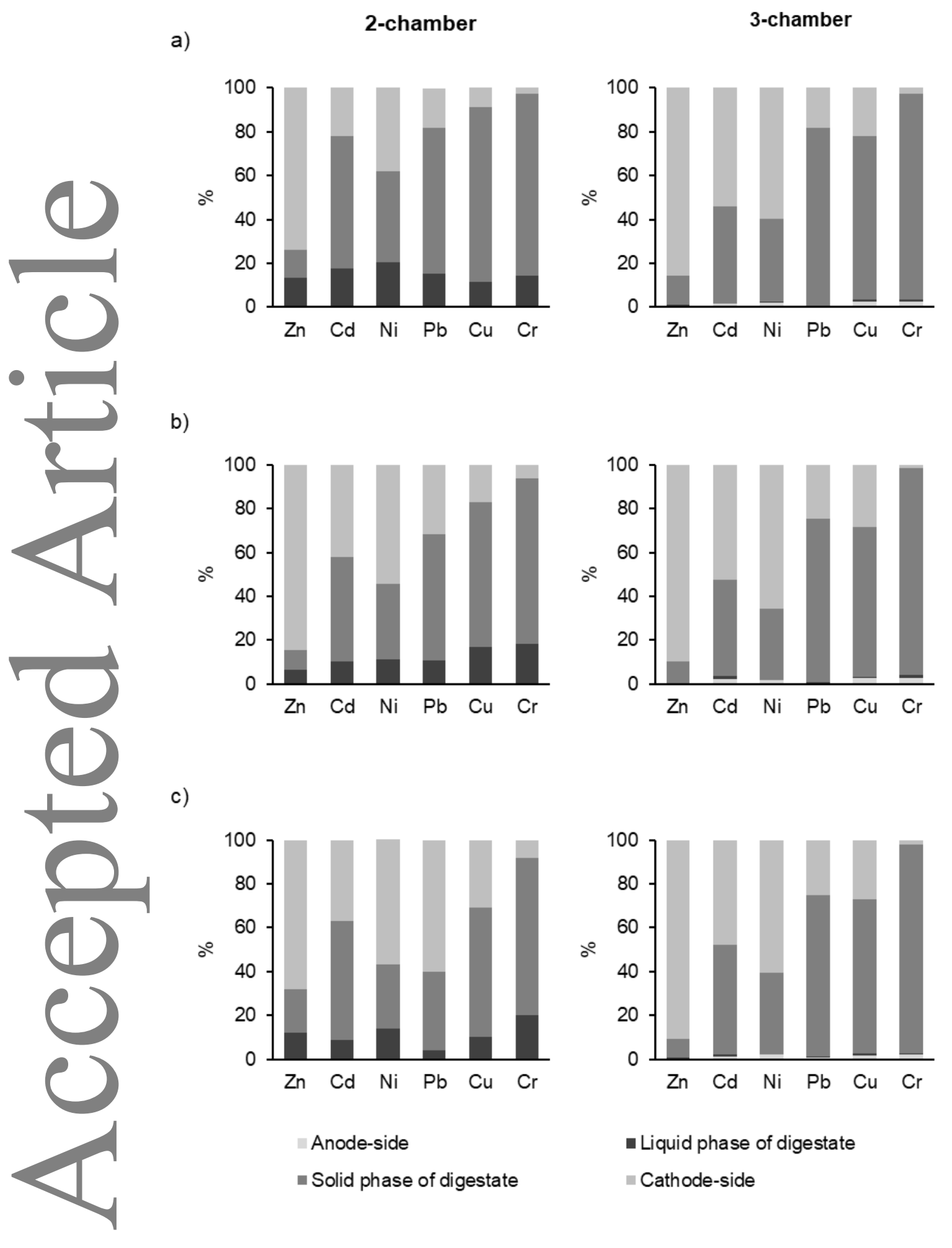

Fig. 5 Distribution of heavy metals (\%) in different parts of ED cell at the end of 2-chamber and 3chamber experiments, after a) $7 d$, b) $9 d$ and c) $11 d$ 
a)

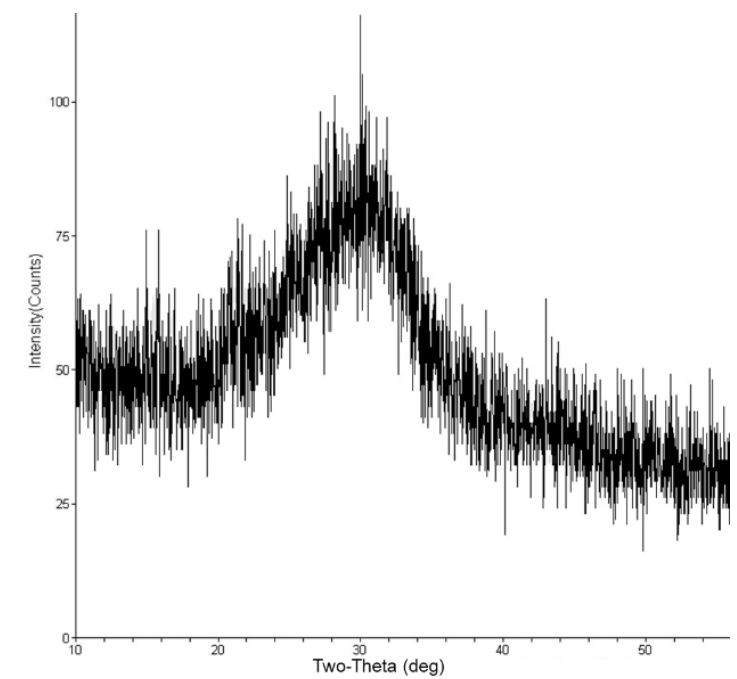

b)

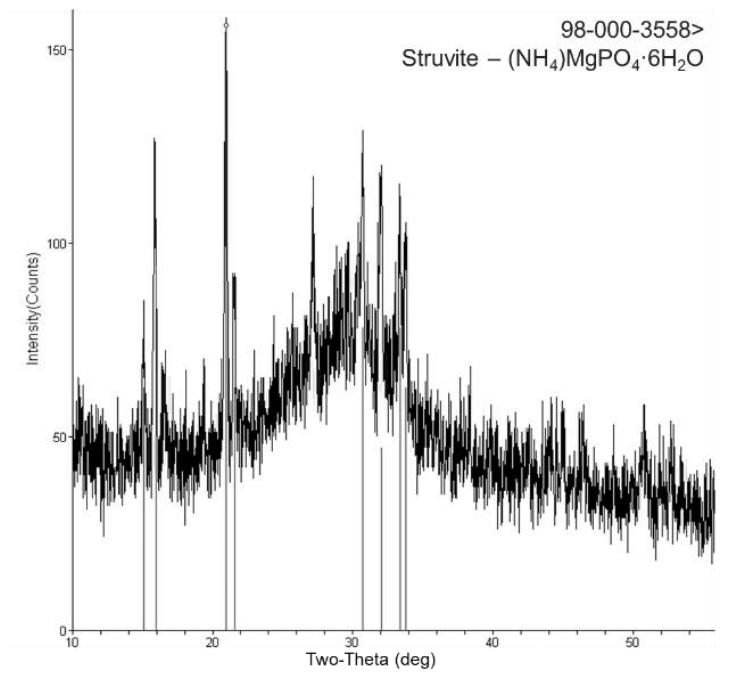

c)

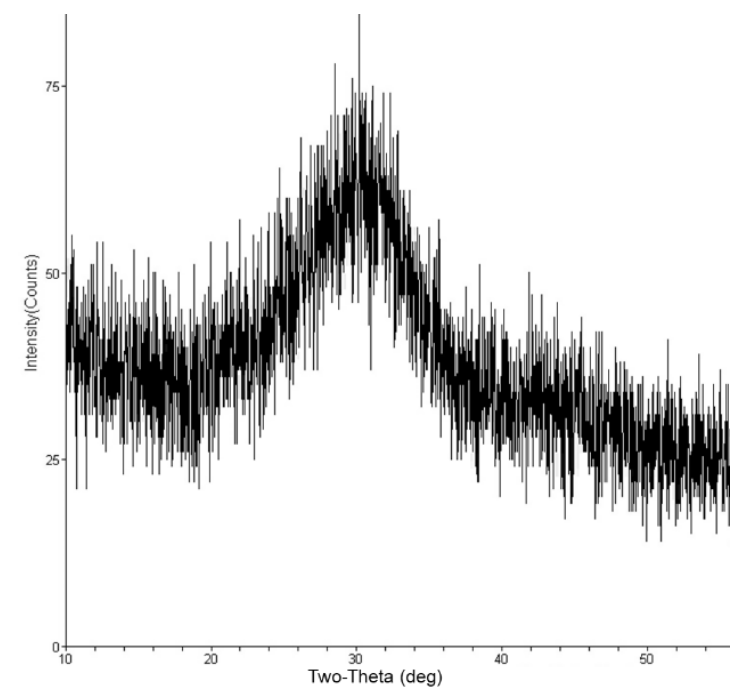

3-chamber
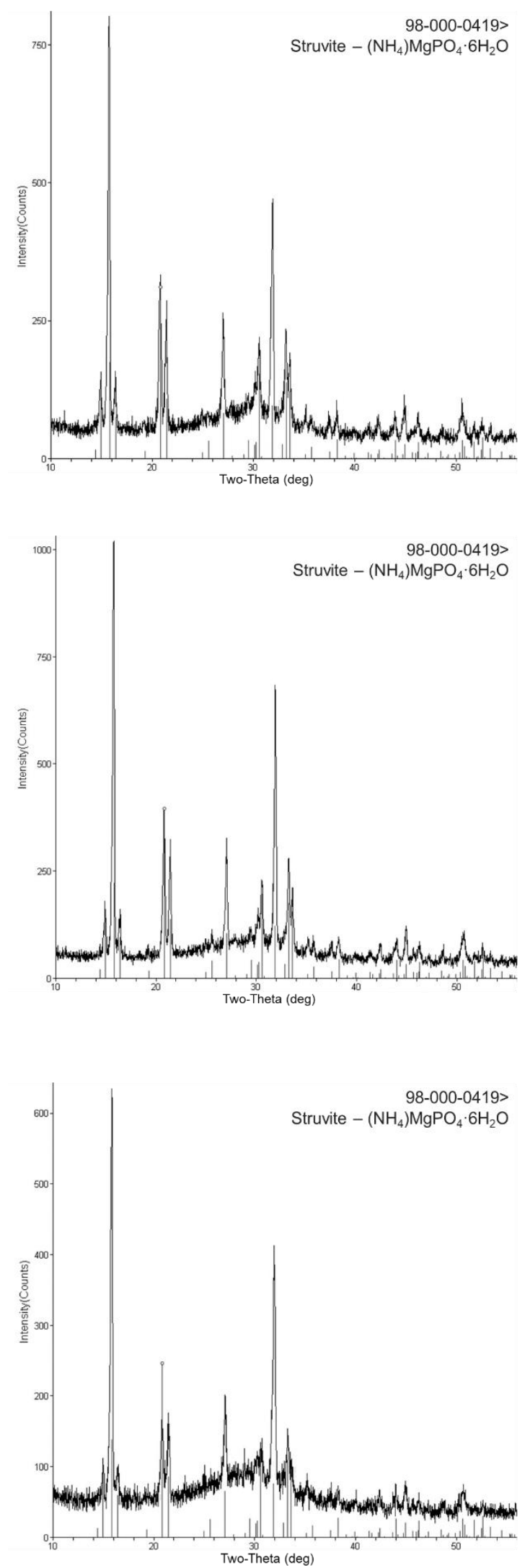

Fig. 6 X-ray diffraction of the precipitates obtained after struvite-inducing reaction from the 2- and 3chamber experiments after a) $7 d$, b) $9 d$ and c) $11 d$ 
2-chamber: $7 \mathrm{~d}$

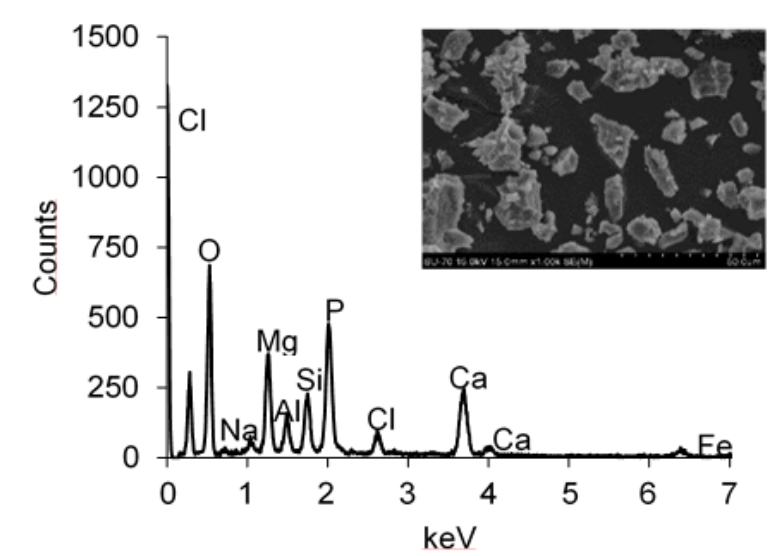

3-chamber: $7 \mathrm{~d}$

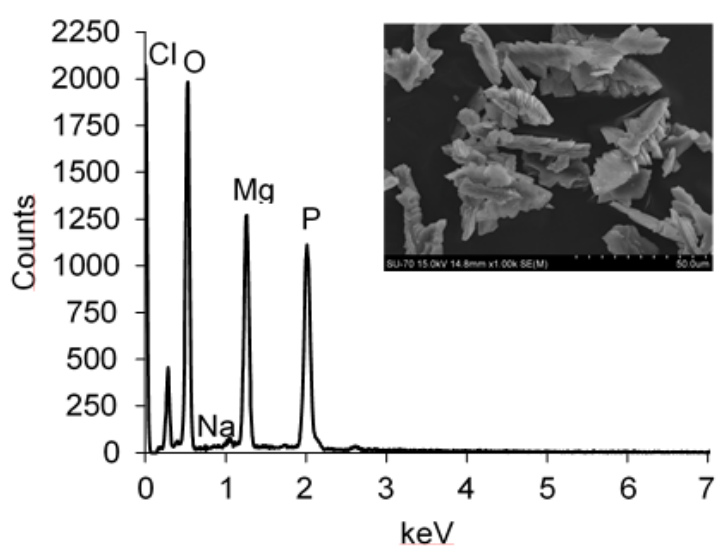

2-chamber: $9 \mathrm{~d}$

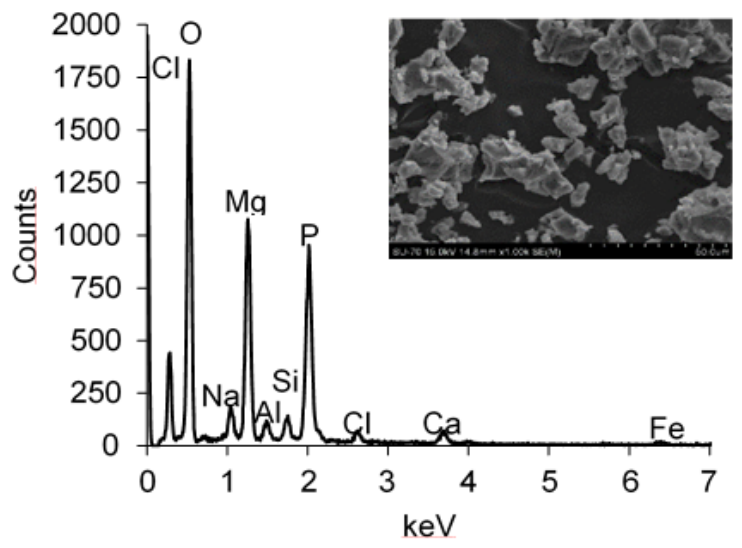

3-chamber: $9 \mathrm{~d}$

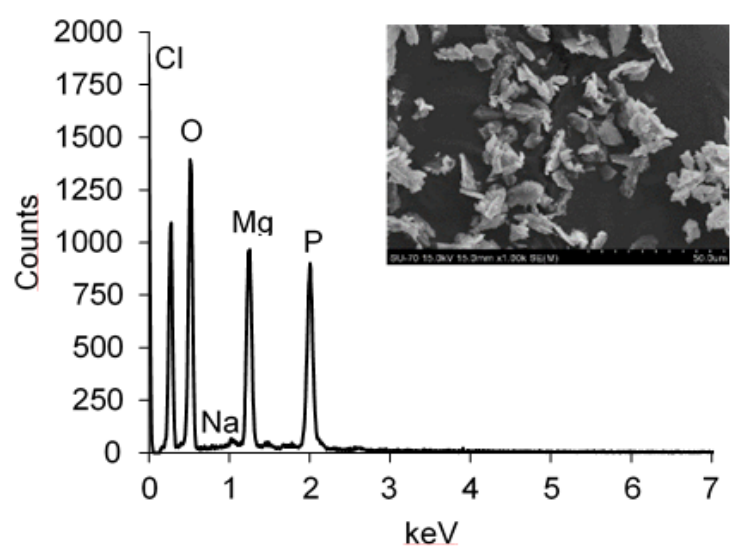

2-chamber: $11 \mathrm{~d}$

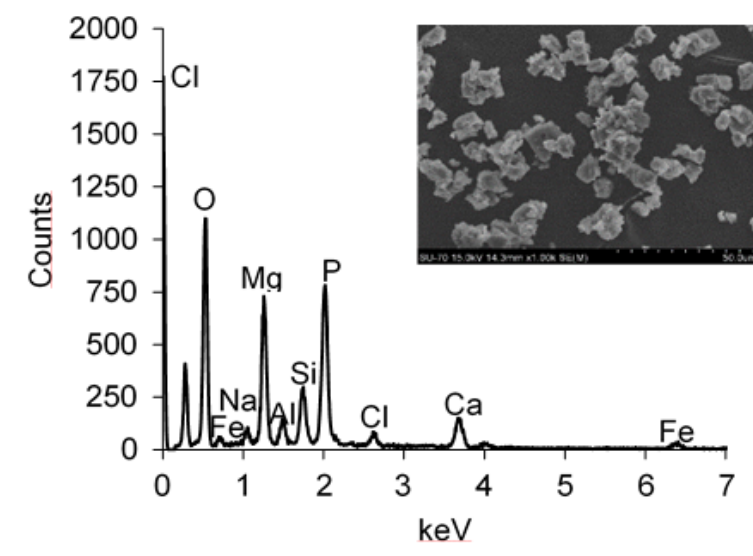

3-chamber: $11 \mathrm{~d}$

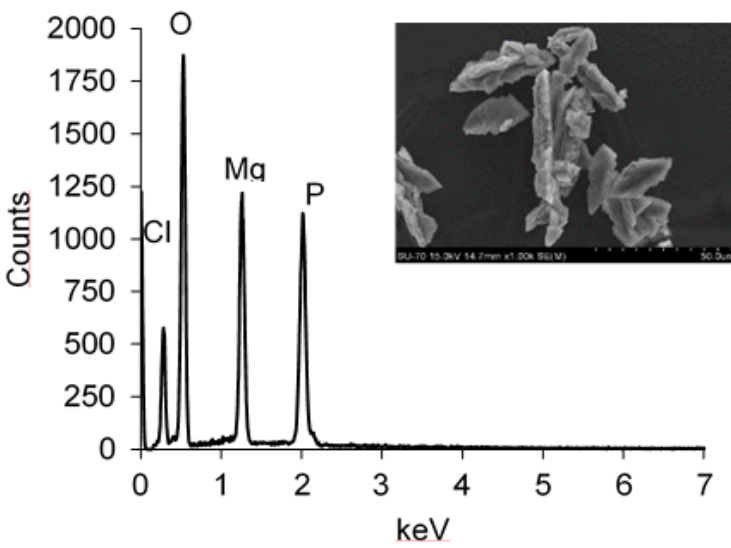

Fig. 7 Spectra obtained from EDS of the harvested precipitates from a) liquid phase solutions resulted from 2-chamber experiments and b) anolyte solutions from the 3 chamber experiments, after $7 d, 9 d$ and $11 \mathrm{~d}$. SEM pictures are inset in EDS spectra

This article is protected by copyright. All rights reserved. 